\title{
VARIATIONS IN SERUM CALCIUM AND PHOSPHORUS DURING PREGNANCY. III. THE EFFECT ON THE FETAL CIRCULATION
}

\author{
By J. W. MULL \\ (From the Laboratory of the Maternity Hospital and Department of Obstetrics, School of \\ Medicine, Western Reserve University, Cleveland)
}

(Received for publication April 23, 1936)

In an earlier paper (1) we demonstrated that pregnancy causes a fall in both the calcium and inorganic phosphorus content of the maternal blood. This fall, averaging almost 5 per cent at its point of greatest effect, about six weeks before delivery, carries the calcium level below the lower limit of the range for normal non-pregnant women (2). No significance has been attached to this as regards the growing fetus since it has long been believed that the demands of the child were met at the expense of the mother. This belief was in part substantiated by evidence that the calcium and phosphorus content of the cord blood invariably runs higher than that of the maternal blood drawn at the same time (3). It seemed to us, however, that this question should not be closed without an investigation of the possibility of some correlation between the maternal and fetal circulations.

The subjects, young women ranging from 16 to 36 years of age, delivered in the hospital, were normal pregnant patients with one exception, a toxemia of pregnancy. The cord blood was obtained from the residual end of the cord immediately after the delivery of the baby. Venous blood was drawn from the mother at approximately the same time. The calcium and phosphorus determinations were made by the same methods, with the same precautions, used in our earlier investigations. The serum was removed from the clot as soon as practical, 30 to $60 \mathrm{~min}$ utes after drawing, and the determinations made on clear fresh aliquots.

The results are embodied in Tables I and II. In both, the cord findings are tabulated in columns according to short interval ranges of the corresponding maternal values. The averages of these tabulations indicate very clearly that the levels of the cord blood, although without an exception higher than the maternal, are dependent on those of the maternal circulation. Not only do the av-
TABLE I

Distribution of the serum calcium findings of the cord blood on the basis of the corresponding determinations of venous calcium

(Figures given in $\mathrm{mgm}$. Ca per $100 \mathrm{ml}$. serum)

\begin{tabular}{c|c|c|c|c}
\hline \hline 8.0 to 8.49 & 8.5 to 8.99 & 9.0 to 9.49 & 9.5 to 9.99 & 10.0 to 10.49 \\
\hline 10.53 & 10.55 & 10.24 & 11.35 & 12.40 \\
& 10.70 & 11.67 & 10.54 & 12.60 \\
& 10.30 & 10.24 & 11.44 & 10.90 \\
& 10.55 & 11.93 & 11.94 & 11.90 \\
& 10.55 & 11.81 & 11.62 & 11.90 \\
& 9.94 & 10.82 & 10.75 & 12.50 \\
& 10.35 & 10.65 & 11.52 & 11.10 \\
& 9.00 & 11.13 & 11.00 & 11.70 \\
& 11.00 & 10.45 & 11.10 & \\
& $10.27 *$ & 9.96 & 11.90 & \\
& 10.58 & 10.04 & 13.10 & \\
& 10.33 & 10.75 & 12.90 & \\
& 9.91 & 11.21 & 11.60 & \\
& 10.51 & 10.09 & 12.00 & \\
& & 10.64 & 11.20 & \\
& & 10.45 & 11.35 & \\
& & 11.00 & & \\
& & 11.50 & & \\
& & 11.60 & & \\
& & 10.20 & & \\
& & 11.02 & & \\
\hline Average & 10.32 & 10.70 & & \\
Range & 9.00 to & 9.96 to & 10.54 to & 10.90 to \\
& 11.00 & 11.93 & 13.10 & 12.50 \\
\hline
\end{tabular}

*A toxemia patient, blood pressure $188 / 128$, calcium findings not unusual.

erages show a definite rise as the maternal values increase, but the maximum and minimum findings for each column, with one exception in each table. show the same rise.

No effort has been made so far to establish a normal range for either calcium or phosphorus in the fetal circulation, nor have definite minimum requirements been established for proper growth and development. We have only shown that the calcium and phosphorus findings in cord blood tend quite definitely to vary with the findings of the corresponding maternal blood. But, when the blood calcium of the average normal pregnant 
TABLE II

Distribution of the serum phosphorus findings of cord blood on the basis of the corresponding determinations of venous phosphorus

(Figures given in mgm. $P$ per $100 \mathrm{ml}$. serum)

\begin{tabular}{|c|c|c|c|c|}
\hline 2.0 to 2.99 & 3.0 to 3.99 & 4.0 to 4.99 & 5.0 to 5.99 & 6.0 to 6.99 \\
\hline $\begin{array}{l}6.50 \\
5.00 \\
3.73 \\
5.27\end{array}$ & $\begin{array}{l}\mathbf{5 . 2 0} \\
\mathbf{5 . 5 0} \\
\mathbf{3 . 8 0} \\
\mathbf{5 . 4 0} \\
\mathbf{4 . 8 0} \\
\mathbf{5 . 4 8} \\
\mathbf{6 . 5 2} \\
\mathbf{5 . 1 3} \\
\mathbf{5 . 0 0} \\
\mathbf{5 . 5 6} \\
\mathbf{5 . 5 1} \\
\mathbf{4 . 3 5} \\
\mathbf{3 . 9 4} \\
\mathbf{5 . 2 8} \\
\mathbf{5 . 6 2} \\
\mathbf{5 . 8 3} \\
\mathbf{4 . 1 7} \\
\mathbf{5 . 2 7} \\
\mathbf{5 . 8 8}\end{array}$ & $\begin{array}{l}\mathbf{5 . 1 0} \\
\mathbf{6 . 5 0} \\
\mathbf{5 . 6 0} \\
\mathbf{5 . 9 0} \\
\mathbf{5 . 6 5} \\
\mathbf{6 . 0 5} \\
\mathbf{6 . 6 3} \\
\mathbf{5 . 5 3} \\
\mathbf{6 . 5 8} \\
\mathbf{5 . 8 8} \\
\mathbf{5 . 7 0} \\
\mathbf{5 . 8 8} \\
\mathbf{6 . 7 9} \\
\mathbf{5 . 7 2} \\
\mathbf{5 . 8 5} \\
\mathbf{6 . 9 9} \\
\mathbf{5 . 6 3} \\
\mathbf{6 . 5 1} \\
\mathbf{6 . 7 0} \\
\mathbf{6 . 7 2} \\
\mathbf{6 . 4 7} \\
\mathbf{7 . 1 8}\end{array}$ & $\begin{array}{l}7.30 \\
6.10 \\
7.10 \\
6.30 \\
7.20 \\
5.70 \\
5.60 \\
8.97 \\
5.88 \\
6.98 \\
7.07 \\
6.90^{*}\end{array}$ & $\begin{array}{l}7.60 \\
7.10 \\
6.95\end{array}$ \\
\hline $\begin{array}{l}\text { Average } 5.12 \\
\text { Range } 3.73 \text { to } \\
6.50\end{array}$ & $\begin{array}{c}5.17 \\
3.80 \text { to } \\
6.52\end{array}$ & $\begin{array}{c}6.15 \\
5.10 \text { to } \\
7.18\end{array}$ & $\begin{array}{l}6.75 \\
5.60 \text { to } \\
8.97\end{array}$ & $\begin{array}{c}7.22 \\
6.95 \text { to } \\
7.60\end{array}$ \\
\hline
\end{tabular}

* A toxemia patient, blood pressure $188 / 128$, phosphorus findings not unusual.

woman is depressed below the lower limits of the normal range, it is not hard to conclude that the cord values found in such instances are below the levels optimal for the fetus, and that impairment of bone and tooth development may thus result in utero. The value of maintaining the calcium and phosphorus levels of the blood during pregnancy is, therefore, possibly more important to the development of the fetus than to the health of the patient herself.

\section{CONCLUSIONS}

It has been demonstrated that, although higher, the calcium and phosphorus levels of cord blood are dependent on the levels of the maternal blood.

These findings suggest that the lower values of cord blood, resulting from the lowered maternal values usually found in pregnancy, may represent an inadequate availability of calcium and phosphorus for fetal metabolism.

\section{BIBLIOGRAPHY}

1. Mull, J. W., and Bill, A. H., Variations in serum calcium and phosphorus during pregnancy. I. Normal variations. Am. J. Obst. and Gynec., 1934, 27, 510.

2. Mull, J. W., and Bill, A. H., The normal range of calcium and inorganic phosphorus in the serum of healthy non-pregnant women. J. Lab. and Clin. Med., 1933, 18, 1034.

3. Mull, J. W., and Bill, A. H., Calcium and inorganic phosphorus content of prenatal and postpartum serum. Am. J. Obst. and Gynec., 1932, 23, 807. 